Jurnal IImiah AL-Jauhari (JIAJ)

Volume 2 No 2, Desember 2017

ISSN: 2541-3430

E-ISSN: 2541-3449

Halaman 144-158

\title{
Eksistensi Wanita Karier terhadap Pembentukan Kepribadian Anak pada Aparatur Sipil Negara di Lingkungan Kantor Kementerian Agama Kota Gorontalo
}

Oleh: Suharty Rahim

\begin{abstract}
Abstrak
Wanita karier dalam pembahasan tesis ini adalah seorang ibu yang berkiprah pada dunia kerja dan mampu mengasuh dan mendidik anak-anaknya, sehingga daripadanya dapat memberi dampak posisitif yang cukup besar kepada anak dalam hal pembentukan kepribadian anak.

Hal ini menunjukkan bahwa; upaya yang dilakukan oleh wanita karier Aparatur Sipil Negara di lingkungan Kantor Kementerian Agama Kota Gorontalo dalam pembentukan kepribadian anak di antaranya, (a) melakukan pendidikan aqidah dan akhlak secara intesif kepada anak, (b) memberikan contoh ketaladan yang baik kepada anak pada semua aspek, (c) memasukkan anak ke lembagalembaga pendidikan agama, atau mengikutsertakan anak pada setiap kegiatan keagamaan, serta membiasakan anak membaca buku-buku tentang Aqidah dan Akhlak, (d) melakukan pengawasan terhadap semua aktivitas anak disertai dengan penetapan puneshman dan reward;
\end{abstract}

\section{Kata Kunci: Wanita Karier, Kepribadian Anak}

\section{A. Pendahuluan}

Munculnya gagasan tentang peran wanita bekerja di luar rumah atau lebih dipopulerkan dengan istilah wanita karier diawali dengan asumsi yang mengatakan bahwa perempuan adalah manusia yang paling berjasa bagi lahirnya generasi baru yang kuat dan tangguh, yang merasa diri termarjinalkan bahkan nyaris tidak diberikan peluang untuk berkiprah sama seperti laki-laki ${ }^{1}$

Memang adalah hal yang wajar jika sekiranya hal ini nyata dipersoalkan, mengingat realita bahwa peralihan fungsi dan peran secara langsung ataupun tidak

\footnotetext{
${ }^{1}$ Armahedi Mahzar “Wanita dalam Islam” kata pengantar, dalam buku Fatima Mernissi, Woman And Islam: An Historical and Theological Enqiury diterjemahkan oleh Yasiar Radianti dengan judul Wanita dalam Islam (Bandung: Pustaka, 2011) h. 5.
} 
langsung akan mempengaruhi keseimbangan ekosistem alam. Melihat implikasi dari adanya gerakan ini secara realistis kita menyaksikan pelbagai kawasan aktivitas kaum laki-laki perlahan-lahan mulai diduduki dan bisa dilaksanakan oleh wanita. Hal ini kemudian yang menjadikan banyak kaum laki-laki merasa tersaingi. Bahkan menjadi sebuah alasan yang selalu dilontarkan bahwa para wanita meskipun memiliki tanggung jawab besar terhadap suami dan anak-anak, tetapi mereka telah banyak yang mengusai publik. Disinilah problem itu muncul. Dengan aktivitasnya yang berorientasi di luar rumah, maka obsesi memberi pengaruh terhadap tanggung jawabnya di dalam rumah sangat besar.

Meskipun demikian, Islam menempatkan wanita dalam kedudukan yang tinggi sama dengan laki-laki. Dari sisi insaniyyah nya wanita dan laki-laki adalah sama, tidak ada penghalang dikarenakan perbedaannya dalam meraih kedudukan yang tinggi disi Allah. Sebagaimana firman Allah dalam QS. Ali Imran (3): 195

Terjemahnya:

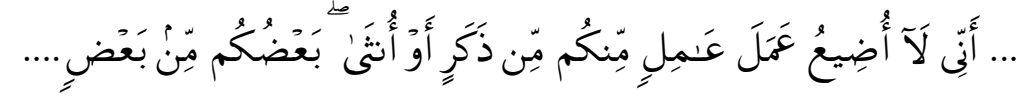

...Sesungguhnya Aku tidak menyia-nyiakan amal orang-orang yang beramal di antara kamu, baik laki-laki atau perempuan, sebagian kamu adalah turunan dari sebagian yang lain... ${ }^{2}$

Firman Allah dalam QS. Al-Ahzab (33): 35



Terjemahnya:

Sesungguhnya laki-laki dan perempuan yang muslim, laki-laki dan perempuan yang mu'min, laki-laki dan perempuan yang tetap dalam keta'atannya, laki-laki dan perempuan yang benar, laki-laki dan perempuan yang sabar, laki-laki dan perempuan yang khusyu', laki-laki dan perempuan yang bersedekah, laki-laki dan perempuan yang berpuasa, lakilaki dan perempuan yang memelihara kehormatannya, laki-laki dan perempuan yang banyak menyebut Allah, Allah telah menyediakan untuk mereka ampunan dan pahala yang besar. ${ }^{3}$

Berdasarkan fiman Allah tersebut mengindikasikan bahwa Islam memberikan kedudukan yang sama antara laki-laki dan perempuan, sebab untuk

${ }^{2}$ Departemen Agama, Al-Quran dan Terjemahnya (Jakarta: Gema Risalah Press Bandung, 2009), h. 135.

${ }^{3}$ Ibid., h. 837 
membangun peradaban manusia bukan hanya tanggung jawab laki-laki, tetapi juga perempuan yang menjadi inti keluarga, khususnya dalam kehidupan berumah tangga. Dalam kehidupan sosial diperlukan keberimbangan antara laki-laki dan perempuan. Islam menilai bahwa laki-laki tidak sama dengan perempuan dalam menyikapi berbagai macam problem kehidupan. Laki-laki dan perempuan harus bekerja sama untuk membangun kesuksesan masa depan bersama. Di dalam Islam kita telah mengenal Sayyidah Fatimah Azzahra (putri Rasulullah) yang membela dan mendampingi perjuangan Ayahnya, Sayyidah Maryam yang dengan kelembutannya menjaga sang kekasih Allah, Isa Almasih, juga Sayyidah Asiah (istri Firaun) yang dengan kesabarannya bisa terjaga dari pengaruh buruk Firaun. ${ }^{4}$

Agama Islam selalu menghendaki agar wanita melakukan pekerjaan/karier yang tidak bertentangan dengan kodrat kewanitaannya dan tidak mengungkung haknya di dalam bekerja, kecuali pada aspek-aspek yang dapat menjaga kehormatan dirinya, kemuliaannya dan ketenangannya serta menjaganya dari pelecehan dan pencampakan. Hal ini beralasan logis akan fenomena dalam kehidupan menunjukkan bahwa wanita karier sangat dibutuhkan untuk membantu kehidupan perekonomian seperti; membantu suaminya dalam menafkahi keluarga dalam bentuk ketersediaan sandang, pangan dan papan keluarga, serta kebutuhan sekunder lainnya yang dibutuhkan oleh anggota keluarga.

Di Kota Gorontalo khususnya wanita karier Aparatur Sipil Negara di lingkungan Kantor Kementerin Agama Kota Gorontalo, keberadaannya dianggap sangat membantu memperkuat ekonomi keluarga baik bersifat primer maupun bersifat sekunder seperti; dapat membantu suaminya untuk membeli dan memenuhi kebutuhan makan dan minum keluarga, dapat membantu menyediakan tempat tinggal keluarga, dapat membeli pakaian anak-anaknya, dan dapat membiayai anaknya dalam studi, serta kegiatan-kegiatan sosial lainnya.

Berdasarkan fenomena tersebut menunjukkan bahwa, eksistensi wanita karier Aparatur Sipil Negara di Lingkungan Kantor Kementerin Agama Kota Gorontalo tidak hanya sebagai pelengkap keluarga tetapi benar-benar menjadi penopang utama dalam menciptakan kesejahteraan keluarga. Wanita karier tersebut disamping dapat menjalankan tugasnya sebagai ibu yang mampu mengasuh dan mendidik anak-anaknya, juga dapat berkiprah pada dunia kerja secara baik sehingga daripadanya dapat memberi dampak posisitif yang cukup besar kepada anak dalam hal pembentukan kepribadian anak, karena anak termotivasi melihat karier ibunya.

Di samping itu, keberadaan wanita karier Aparatur Sipil Negara di lingkungan Kantor Kementerin Agama Kota Gorontalo dapat memberi motivasi bagi kaum pria untuk meningkatkan kinerja dalam suatu organisasi, sebab wanita karier tersebut diberikan peluang yang cukup besar untuk menduduki posisi sebagai kepala pada satuan unit kerja seperti; Kepala Seksi, Ketua Pokjawas dan Kepala Madrasah, juga sebagai ketua kepanitiaan pada kegiatan-kegiatan instansi dan keumatan. Hanya saja dalam kaitannya dengan keumatan yang bersifat

\footnotetext{
${ }^{4}$ Imam Khomaini dalam Majalah Payam Khonewodeh No: 52, 1384 H., h. 14
} 
relegius tetap berpegang kepada landasan agama yaitu mendahulukan kaum pria daripada wanita. Misalnya; menjadi Kepala Kantor Kementerian Agama, Kepala Kantor Urusan Agama, Ketua Majelis Ulama Daerah, Ketua Ta’mirul Masjid, kesemuanya tetap dari kalangan pria dan bukan wanita.

Berdasarkan hal di atas mendorong penulis untuk mengkaji secara langsung kondisi riil yang ada, apakah kewajaran wanita karier khususnya Aparatur Sipil Negara di lingkungan Kantor Kementerin Agama di Kota Gorontalo memberi dampak terhadap keluarga terutama pembentukan kepribadian anak ataukah sebaliknya.

Permasalahan dalam penelitian ini dapat dirumuskan sebagai berikut:

1. Bagaimana upaya yang dilakukan wanita karier Aparatur Sipil Negara di lingkungan Kantor Kementerian Agama Kota Gorontalo dalam pembentukan kepribadian anak?

2. Bagaimana kendala yang dihadapi wanita karier Aparatur Sipil Negara di lingkungan Kantor Kementerian Agama Kota Gorontalo dalam melaksanakan tanggung jawabnya terhadap pembentukan kepribadian anak, dan bagaimana solusinya?

\section{B. Hakikat Wanita Karier}

Dalam Kamus Besar Bahasa Indonesia dikatakan bahwa wanita karier adalah perempuan dewasa, kaum putri yang berkecimpung dalam kegiatan profesi (usaha perkantoran) ${ }^{5}$. Wanita juga adalah istilah halus dalam bahasa Indonesia. Kata ini bersinonim dengan kata perempuan yang berasal dari bahasa Melayu. Umumnya kalangan feminisme Indonesia lebih suka menggunakan kata perempuan daripada kata wanita. ${ }^{6}$

Dalam konstitusi di Indonesia, wanita memiliki kedudukan yang sama dengan laki-laki. Hal ini sebagaimana disebutkan dalam UUD tahun 1945 Bab XII pasal 27, bahwa "semua warga negara bersamaan kedudukannya di dalam hukum dan pemerintahan", hal ini mengindikasikan bahwa antara laki-laki dan perempuan mempunyai hak, kedudukan dan peran yang sama untuk berpartisipasi dalam pembangunan nasional. Namun pada kenyataannya umumnya sebagian perempuan malah sangat dibatasi dalam hal ruang geraknya.

Beragam corak sosio-kultural, tingkat pendidikan, dan berbagai aspek lainnya telah mengakibatkan berbagai pandangan tentang eksistensi wanita dalam masyarakat. Secara umum saat ini model pemahaman tentang wanita terbagi atas dua versi yaitu antara pemahaman Barat dan pemahaman Timur.

Dalam dunia Barat, paham wanita karier muncul sebagai suatu bentuk keinginan untuk setara dengan laki-laki dalam segala hal yang sering mereka

\footnotetext{
${ }^{5}$ Departemen Pendidikan Nasional, Kamus Besar Bahasa Indonesia, (Jakarta : Balai Pustaka, 2010) h. 1201.

${ }^{6}$ Armahedi Mahzar “Wanita dalam Islam” Kata Pengantar, dalam buku Fatima Mernissi, Woman And Islam: An Historical and Theological Enqiury diterjemahkan oleh Yasiar Radianti dengan judul Wanita dalam Islam (Bandung: Pustaka, 2011) h. v.
} 
gaungkan dengan istilah "Kesetaraan Gender". Selain itu, dari sisi historis, terjunnya kaum wanita ke lapangan untuk bekerja dan berkarier semata-mata karena unsur keterpaksaan. Ada dua hal penting yang melatarbelakanginya:

Pertama, terjadinya revolusi industri mengundang arus urbanisasi kaum petani pedesaan, tergiur untuk mengadu nasib di perkotaan, karena himpitan sistem kapitalis yang melahirkan tuan-tuan tanah yang rakus. Kedua, kaum kapitalis dan tuan-tuan tanah yang rakus sengaja menggunakan momen terjunnya kaum wanita dan anak-anak, dengan lebih memberikan porsi kepada mereka di lapangan pekerjaan, karena mau diupah lebih murah daripada kaum lelaki, meskipun dalam jam kerja yang panjang. ${ }^{7}$

Kehidupan yang dialami oleh wanita di Barat yang demikian mengenaskan, sehingga menggerakkan nurani sekelompok pakar untuk membentuk sebuah organisasi kewanitaan yang diberi nama "Humanitarian Movment (HM)" yang bertujuan untuk membatasi eksploitasi kaum kapitalis terhadap para buruh, khususnya dari kalangan anak-anak. Organisasi ini berhasil mengupayakan undang-undang perlindungan anak, akan tetapi tidak demikian halnya dengan kaum wanita. Mereka tetap saja dihisap darahnya oleh kaum kapitalis tersebut. Hingga saat ini pun, kedudukan wanita karier di Barat belum terangkat dan masih saja mengenaskan, meskipun sudah mendapatkan sebagian hak mereka. Di antara indikasinya, mendapatkan upah lebih kecil daripada kaum laki-laki, keharusan membayar mahar kepada laki-laki bila ingin menikah, keharusan menanggung beban penghidupan keluarga bersama sang suami, dan lain sebagainya

Sedangkan menurut pandangan Islam, Wanita berkarier tidak dilarang dan tidak menolak wanita menjadi pemimpin selain di rumah tangga. Sebab tidak ditemukan dasar yang kuat bagi larangan seorang perempuan untuk berkarier atau menjadi pemimpin di ruang publik. Justru sebaliknya, ditemukan sekian banyak dalil keagamaan yang dapat dijadikan dasar untuk mendukung hak-hak perempuan dalam semua aspek. ${ }^{8}$ Salah satunya adalah QS. at-Taubah 9:7

Terjemahnya:

Orang-orang yang beriman laki-laki dan perempuan, sebagian mereka adalah auliya' bagi sebagian yang lain. Mereka menyuruh yang makruf, mencegah yang munkar, melaksanakan sholat, menunaikan zakat, dan mereka taat kepada Allah dan Rasul-Nya. Mereka itulah akan dirahmati Allah, Sesungguhnya Allah Maha Perkasa lagi Maha Bijaksana. ${ }^{9}$

Berdasarkan ayat al-Qur'an tersebut yang menjadi dasar bagi Quraish Shihab untuk mengatakan bahwa perempuan dibolehkan berkarier atau menjadi pemimpin di ruang publik, sama juga dengan yang dikemukakan Justice Aftab Husain bahwa, prinsip yang mendasari kebolehan wanita berkarier adalah prinsip

\footnotetext{
${ }^{7}$ Ibid., h. 53.

${ }^{8}$ Quraish Shihab, Wawasan al-Qur'an Tafsir Maudhu'i atas Pelbagai Persoalan Umat (Bandung: Mizan, 2015), h. 346

${ }^{9}$ Departemen Agama RI, Al-Qur'an dan Terjemahnya.... h. 529.
} 
yang berlaku dalam segala hal adalah kebolehan, sampai ada dalil yang menunjukkan ketidakbolehan. ${ }^{10}$ Di samping itu tidak ditemukan dalam ayat-ayat al-Qur'an atas larangan bagi perempuan untuk menjadi berkarier atau menjadi pemimpin di ruang publik, hadis-hadis Nabi juga diam dalam masalah ini.

Dengan ilmu pengetahuan dan keterampilan yang dimiliki oleh setiap orang, termasuk kaum wanita, mereka mempunyai hak untuk bekerja dan menduduki jabatan-jabatan tertinggi. Hanya ada jabatan yang oleh sementara ulama dianggap tidak dapat diduduki oleh kaum wanita, yaitu jabatan Kepala Negara (Al-Imamah Al-'Uzhma) dan Hakim. Namun, perkembangan masyarakat dari saat ke saat mengurangi pendukung larangan tersebut.

Jamaluddin Muhammad Mahmud berpendapat bahwa berdasarkan kitab fiqih, wanita itu dapat bertindak sebagai pembela dan penuntut dalam berbagai bidang. ${ }^{11}$ Islam sendiri sebenarnya sama sekali tidak membelenggu kaum wanita dan tidak mengikatnya kecuali dengan tali moral, yang demikian dapat mengangkat derajat dan menambah kehormatan dirinya. Islam juga menarik tangan wanita lalu menyelamatkannya dari kedzalimn Jahiliyah. Ketika Allah mengangkat muhammad sebagai Rasul, maka pada sat itu Allah mengangkat tangan wanita dan memberikan kepadanya kebebasan yang benar serta rasional. Allah memberikan hak kepada wanita secara utuh tidak kurang sedikitpun, menjadikannya sebagai pendamping laki-laki dalam melaksanakan kewajiban dan penerapan hukum.

Wanita mempunyai kedudukan sama dengan laki-laki kecuali dalam beberapa hal yang harus disesuaikan dengan nalurinya. Karenanya, dalam hal ini wanita memperoleh prioritas untuk dimuliakan dan diperlakukan lemah lembut sebagimana layaknya. Keberadaan wanita dalam Islam yang begitu sempurna ini tidak dijumpai dalam agama lain. Islam sebenarnya tidak melarang seorang wanita bekerja atu melalui kegitatan di luar rumah, asal tidak melampaui batas kodrat kewanitaannya.

\section{Konsep Kepribadian Anak}

Kepribadian adalah ciri atau karakteristik atau gaya atau sifat khas dari diri seseorang yang bersumber dari bentukan-bentukan yang diterima dari lingkungan, misalnya, keluarga pada masa kecil, dan juga bawaan seseorang sejak lahir. ${ }^{12}$ Kepribadian adalah sebuah kata yang menandakan ciri pembawaan dan pola kelakuan seseorang yang khas bagi pribadi itu sendiri. Kepribadian meliputi tingkah laku, cara berpikir, perasaan, gerak hati, usaha, aksi, tanggapan terhadap kesempatan, tekanan, dan cara sehari-hari dalam berintegrasi dengan orang lain.

\footnotetext{
${ }^{10}$ Justice Aftab Hussain, Status of Women in Islam (Lahore: Law Publishing Company,
} 2007), h. 201.

${ }^{11}$ Jamaluddin Muhammad Mahmud, Huquq Al-Mar'at fi Al-Mujtama' al-Islamiy (Kairo, Al-Haiat al-Mishriyat al-Amat, 2006), h. 71.

${ }^{12}$ Sjarkawi, Pembentukan Kepribadian Anak; Peran Moral, Intelektual, Emosional, dan Sosial sebagai Wujud Integritas Membangun Jati Diri (Jakarta:. Bumi Aksara, 2011), h. 11. 
Jika unsur-unsur kepribadian ini menyatakan diri dalam kombinasi berulang-ulang secara khas dan dinamis maka hal demikian dikenal dengan nama gaya kepribadian.

Berdasarkan uraian di atas dapat disimpulkan bahwa kepribadian adalah corak tingkah laku sosial, corak ketakutan, dorongan dan keinginan, corak gerakgerik badan manusia. Tingkah laku yang disebut kepribadian bersifat sadar dan tidak sadar. Hal itu dapat dilihat dari sudut diri manusia dan dari sudut lingkungannya.

Para ahli sependapat bahwa kepribadian itu berkembang dan mengalami perubahan-perubahan. Tetapi di dalam pekembangan itu makin terbentuklah pola-pola yang tetap dan khas, sehingga merupakan ciri-ciri yang unik bagi setiap individu.

Menurut Sjarkawi, faktor-faktor yang mempengaruhi kepribadian seseorang dapat dikelompokkan dalam dua faktor, yaitu faktor internal dan eksternal. $^{13}$

1. Faktor Internal

Faktor internal adalah faktor yang berasal dari dalam diri orang itu sendiri. Faktor internal ini biasanya merupakan faktor genetis atau bawaan. Faktor genetis maksudnya adalah faktor bawaan sejak lahir dan merupakan pengaruh keturunan dari salah satu sifat yang dimiliki salah satu dari kedua orangtuanya atau bisa jadi gabungan atau kombinasi dari sifat kedua orangtuanya.

2. Faktor Eksternal

Faktor eksternal adalah faktor yang berasal dari luar orang tersebut. Faktor eksternal ini biasanya merupakan pengaruh yang berasal dari lingkungan seseorang mulai dari lingkungan terkecilnya, yakni keluarga, teman, tetangga, sampai dengan pengaruh dari berbagai media audiovisual seperti TV dan VCD, atau media cetak seperti koran, majalah dan lain sebagainya.

Ngalim Purwanto membahas faktor-faktor yang mempengaruhi perkembangan kepribadian, yang terbagi dalam tiga faktor, yakni; (1) Faktor Biologi atau seringkali disebut faktor fisiologis yaitu faktor yang berhubungan dengan keadaan jasmani. Keadaan fisik seseorang memegang peranan penting dalam kepribadiannya; (2) Faktor sosial yaitu masyarakat. Yakni manusiamanusia lain disekitar individu yang mempengaruhi individu yang bersangkutan. Termasuk juga disini tradisi-tradisi, adat istiadat, peraturan-peraturan, bahasa dan sebagainya yang berlaku dalam masyarakat itu; (3) Faktor kebudayaan, dalam faktor kebudayaan aspek yang mempengaruhi pembentukan kepribadian nilainilai hidup yang berlaku dalam masyarakat, adat dan tradisi, pengetahuan, ketrampilan, dan bahasa. ${ }^{14}$

Berdasarkan pendapat para ahli di atas, penulis merumuskan faktor dominan yang mempengaruhi pembentukan kepribadian pada dasarnya terdiri dari dua faktor yakni faktor internal dan faktor eksternal. Dari kedua faktor ini yang

\footnotetext{
${ }^{13}$ Ibid., h. 19.

${ }^{14}$ Ngalim Purwanto, Psikologi Pendidikan (Bandung: Remaja Karya, 2010), h. 160.
} 
sangat mempengaruhi adalah faktor eksternal. Sebagaimana haditš Nabi saw. yang artinya sebagai berikut:



Artinya :

"Tiap bayi yang dilahirkan dalam keadaan fitrah, ibu bapaknyalah yang meyahudikan atau menasranikannya. " (HR. Bukhāri, No. 4497). ${ }^{15}$

Kepribadian orangtua dalam mendidik dan membesarkan anaknya pada gilirannya juga akan berpengaruh terhadap kepribadian seorang pada masa pertumbuhan hingga dewasa. Pembentukan kepribadian melalui peningkatan pertimbangan moral menghendaki orangtua di lingkungan rumah tangga bertindak sebagai teman yang dapat bekerja sama dengan anak-anak mereka dalam menyelesaikan segala tugas guna memperbaiki keadaan sosial maupun fisik. Kepribadian orangtua sebagai pengamat yang menggunakan sudut pandang menyeluruh dan objektif akan membantu cara berpikir moral anak ke arah yang luas, objektif, dan menyeluruh.

Berdasarkan uraian di atas, penulis dapat menyimpulkan bahwa upaya pembentukan kepribadian anak dalam Islam ialah mempersiapkan manusia yang beribadah (al-insan al-'abid) serta memiliki sifat-sifat 'ibad al-rahman, seperti berbuat baik dan berusaha mencari rizki.

\section{E. Peranan Orangtua dalam Membentuk kepribadian Anak}

Terkait dengan pembahasan peranan orangtua dalam membentuk kepribadian anak, maka berikut ini akan diuraikan secara rinci Peranan orangtua dalam hal ini ayah dan ibu.

1. Peranan ibu dalam mendidik anak

Peranan orangtua dalam dalam hal ini ibu dalam membentuk kepribadian anak dapat saja ditunjukkan melalui perlakuan, pengarahan kontrol dan penyediaan kelengkapan pendidikan seorang anak. Dalam sebuah rumah tangga Peranan seorang ibu dalam pendidikan anak sangat berarti dan dapat saja membangkitkan motivasi belajar anak hingga tercapai kepribadian yang utuh. Hal ini beralasan, karena keberadaan dan kedekatan anak dan ibu melebihi kedekatannya pada ayah. Baik buruknya pendidikan ibu terhadap anaknya akan berpengaruh besar terhadap perkembangan dan watak anaknya di kemudian hari. ${ }^{16}$

Sesuai dengan fungsi serta tanggung jawabnya sebagai anggota keluarga, berikut ini dirincikan bentuk-bentuk parisipasi seorang ibu terhadap pendidikan anak;

a. Sumber dan pemberi rasa kasih sayang,

b. Pengasuh dan pemelihara,

c. Tempat mencurahkan isi hati,

\footnotetext{
${ }^{15}$ Muhammad bin Ismail Abu Abdillah al-Bukhari, Shahih Bukhari, Juz II (Beirut: Dar Ibn Katsir, 1987), h. 1792.

${ }^{16}$ M. Ngalim Poerwanto, Ilmu Pendidikan Teoritis dan Praktis (Bandung: Remaja Rosdakarya, 2008 ), h. 82.
} 
d. Pengatur kehidupan dalam rumah tangga,

e. Pembimbing pribadi;

f. Pendidik dalam segi emosional. ${ }^{17}$

Dan yang tak kalah penting adalah mendidik anak disesuaikan dengan perkembangan kondisi psikologi anak dan perkembangan zaman di mana anak tersebut lahir dan berinteraksi. Untuk itu orangtua terutama ibu harus jeli dan cerdas dalam membaca situasi dan tanda-tanda zaman, agar bisa mendidik anaknya dengan baik dan sesuai kondisi zamannya.

2. Peranan Ayah dalam pendidikan anak

Dalam berbagai kasus nampak bahwa ayah dalam kedudukannya dalam keluarga dipandang hanya sebagai sosok yang menyediakan seluruh keperluan hidup, sehingga tidak jarang ada di antara para ayah yang melalaikan dan menafikan tanggungjawabnya terhadap pengawasan pendidikan anak. Atau dapat saja seorang ayah berkilah dengan alasan kesibukan dan seluruh pengawasan dan tanggung jawab pendidikan anak hingga pengurusan rumah tangga dibebankan pada ibu.

Anggapan dan kasus di atas, pada dasarnya tidak ada benarnya dan justru dapat dikatakan salah karena sesungguhnya dalam proses pendidikan Peranan dan peran serta seorang ayah akan sangat menentukan warna dan kuilitas pendidikan seorang anak.

Dalam catatan sejarah yang telah diabadikan dalam Al-Qur'an, pendidikan yang paling pokok dan utama sebagaimana yang telah dilakukan Lukman kepada anaknya adalah masalah ketauhidan. Allah berfirman dalam QS. Luqman (31): 13

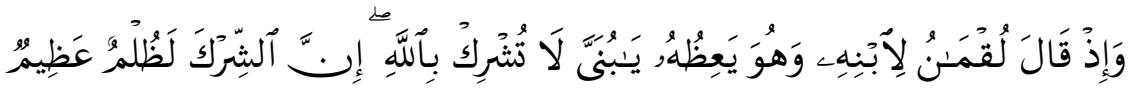

Terjemahnya:

"Dan (Ingatlah) ketika Luqman Berkata kepada anaknya, di waktu ia memberi pelajaran kepadanya: "Hai anakku, janganlah kamu mempersekutukan Allah, Sesungguhnya mempersekutukan (Allah) adalah benar-benar kezaliman yang besar" 18

Mendidik anak sebagaimana yang telah dilakukan Lukman dalam ayat di atas merupakan pendidikan yang sangat urgen. Sebab masalah pendidikan ketauhidan kepada anak menjadi dasar penentu arah perkembangan pendidikan anak selanjutnya.

Lebih lanjut M Ngalim Poerwanto menyebutkan sedikitnya enam Peranan ayah yang dominan dalam upaya mendukung pendidikan anaknya, sebagaimana dirincikan sebagai berikut;

a. Sumber kekuasaan di dalam keluarga,

b. Penghubung intern keluarga dengan masyarakat atau dunia luar,

c. Pemberi perasaan aman bagi seluruh anggota keluarga,

d. Pelindung terhadap ancaman dari luar,

\footnotetext{
${ }^{17}$ Ibid., h. 83.

${ }^{18}$ Departemen Agama RI, Al-Qur'an dan Terjemahnya..., h. 370.
} 
e. Hakim atau yang mengadili jika terjadi perselisihan,

f. Pendidik dalam segi-segi rasional. ${ }^{19}$

Keseluruhan peranan yang disebutkan di atas pada dasarnya ada yang bersifat penciptaan kondisi yang mendukung terlaksananya prosesi pendidikan dan adapula peranannya yang dapat dirasakan langsung manfaatnya dalam pendidikan anak, misalnya pendidik secara rasional dan sumber kekuasaan dalam rumah tangga di mana seorang ayah bertanggung jawab sepenuhnya terhadap kelangsungan hidup dan pendidikan anak.

Di samping itu, sebuah keluarga yang terdiri dari ayah, ibu dan anak, masing-masing saling mempengaruhi, saling membutuhkan. Anak membutuhkan makanan, pakaian, bimbingan dan pendidikan dan sebagainya dari orangtua. Sementara itu orangtua sangat bangga atas kehadiran anak sebagai buah dan pelengkap rumah tangga mereka. Sejak anak dilahirkan, Allah swt. telah menganjurkan kepada ibunya untuk menyusui selama dua tahun sebagaimana dalam QS. Lukman (31): 14



Terjemahnya:

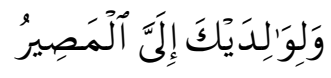

"Dan Kami perintahkan kepada manusia (berbuat baik) kepada dua orang ibu- bapanya; ibunya telah mengandungnya dalam Keadaan lemah yang bertambah-tambah, dan menyapihnya dalam dua tahun. bersyukurlah kepadaku dan kepada dua orang ibu bapakmu, hanya kepada-Kulah kembalimu". ${ }^{20}$

Dalam ayat lain Allah swt. berfirman QS. al-Baqarah (2): 233



\footnotetext{
${ }^{19}$ Ngalim Poerwanto, Ilmu Pendidikan Teoritis dan Praktis..., h. 83.

${ }^{20}$ Departemen Agama RI, Al-Qur'an dan Terjemahnya..., h. 370.
} 
Terjemahnya:

"Para ibu hendaklah menyusukan anak-anaknya selama dua tahun penuh, Yaitu bagi yang ingin menyempurnakan penyusuan. dan kewajiban ayah memberi Makan dan pakaian kepada Para ibu dengan cara ma'ruf". ${ }^{21}$

Mengingat anak lahir dalam pemeliharaan orangtua dan dibesarkan dalam keluarga maka tanpa harus ada yang memerintahkan, orangtua langsung memikul tugas sebagai pendidik, baik yang bersifat sebagai pemelihara, sebagai pengasuh, sebagai pembimbing, sebagai pembina maupun sebagai guru dan pemimpin terhadap anak-anaknya. Ini merupakan tugas kodrati dari tiap-tiap manusia.

Oleh karena itu norma-norma pada anggota-anggota keluarga, baik ayah ibu maupun kakak-kakaknya dapat berpengaruh terhadap anak. Maka orangtua di dalam keluarga harus dan merupakan kewajiban kodrati untuk memperhatikan anak-anaknya serta mendidiknya, sejak anak-anak itu kecil, bahkan sejak anakanak itu masih dalam kandungan. Jadi tugas orangtua mendidik anak-anaknya itu terlepas sama sekali dari kedudukan, keahlian atau pengalaman dalam bidang pendidikan yang legal. Bahkan menurut Imam Ghozali. "Anak adalah suatu amanat Tuhan kepada ibu bapaknya". ${ }^{22}$

Kebiasaan orangtua dan anggota keluarga dalam hal kesusilaan/akhlaq adalah sebagai sebuah tuntunan atau kebiasaan yang ada dalam keluarga akan ditiru di masa dewasa tanpa rasa berat dan akan terjadi setiap saat bagi anak sejak usia dini. Lebih dari itu terdapat juga pertalian emosional antara anak, orangtua dan anak-anaknya, yakni turut berduka cita jika orangtuanya berduka cita dan akan merasa bahagia jika orangtuanya berbahagia. Begitulah keadaan saling pengaruh-mempengaruhi antara anak dengan orangtuanya dan anggota keluarga lainnya, sampai kepada keadaan emosional.

Jelasnya bahwa, upaya pembentukan kepribadian anak akan dapat diwujudkan dengan baik apabila orangtua memiliki kepribadian yang menunjang dalam melaksanakan tugas keprofesionalannya. Kepribadian orangtua tidak hanya menjadi dasar baginya untuk bertingkah laku yang bermoral, tetapi juga sekaligus menjadi model keteladanan bagi para anaknya untuk dicontoh dan dikembangkan.

\section{Kesimpulan}

Berdasarkan uraian pembahasan tersebut, maka dapat disimpulkan beberapa temuan penulis dalam hasil penelitian sebagai berikut;

1. Upaya yang dilakukan oleh wanita karier Aparatur Sipil Negara di lingkungan Kantor Kementerian Agama Kota Gorontalo dalam pembentukan kepribadian anak di antaranya; a) melakukan pendidikan aqidah dan akhlak secara intesif kepada anak melalui mempraktekkan amalan ibadah di dalam kehidupan sehari-hari, seperti shalat lima waktu, puasa, membaca al-Qur'an, dan amalan

\footnotetext{
${ }^{21}$ Ibid. h. 654 .

${ }^{22}$ Al-Ghazali, Ihya 'Ulumuddin, tentang Keajaiban Hati (Jakarta: Yayasan Kesejahteraan Keluarga, 1965), h. 247.
} 
ibadah lainnya. Sedangkan pendidikan akhlak dilakukan dengan cara penanaman etika dan moral dalam keluarga, memperkenalkan kepada anakanak cara hidup menghargai sesama manusia dan makhluk lainnya di lingkungan sekitarnya, serta mengajari anak agar selelu bersyukur dan bersabar untuk mengakui kebesaran Ilahi atas apa yang terjadi kepada makhluk ciptaan-Nya; b) memberikan contoh ketaladan yang baik kepada anak pada semua aspek; c) memasukkan anak ke lembaga-lembaga pendidikan agama, atau mengikutsertakan anak pada setiap kegiatan keagamaan, serta membiasakan anak membaca buku-buku tentang Aqidah dan Akhlak; d) melakukan pengawasan terhadap semua aktivitas anak terutama; cara belajar anak, sikap ramah anak terhadap orang lain, cara bergaul anak dengan yang lebih muda, sederajat atau yang lebih tua, yang kesemuanya disertai dengan penetapan puneshman dan reward atas perbuatan yang mereka lakukan.

2. Kendala yang dihadapi wanita karier Aparatur Sipil Negara di lingkungan Kantor Kementerian Agama Kota Gorontalo dalam melaksanakan tanggung jawabnya terhadap pembentukan kepribadian anak, di antaranya; a) rendahnya tingkat pendidikan dan pengetahuan orang tua dalam mendidik anak; b) kondisi lingkungan masyarakat yang kurang baik; c) kurangnya waktu bagi orang tua untuk berkomunikasi dengan anak-anaknya atau tidak maksimalnya melaksanakan tugas dan tanggungjawab mengurus anak sepanjang hari jika pada saat-saat tertentu ada pekerjaan kantor atau kedinasan yang harus diselesaikan. Adapun upaya yang dilakukan untuk mengatasi kendala-kendala tersebut di antaranya; a) memperbanyak membaca buku-buku tentang bagaimana tatacara wanita karier dalam pembentukan kepribadian anak ke arah yang lebih baik; b) memperbanyak bertanya kepada orang lain yang memiliki pengetahuan dan sukses mendidik anak-anaknya hingga melahirkan anak yang berperilaku baik, tekun ibadah dan mempunyai masa depan yang gemilang; c) menjadikan lingkungan keluarga yang selalu hidup dalam suasana religius; d) membuat time schedule kegiatan yang memungkinkan orang tua dan anak dapat berkomunikasi secara intensif menuju ketercapaian keluarga yang harmonis dan penuh keakraban. 


\section{DAFTAR PUSTAKA}

Alang, Sattu, Kesehatan Mental Dan Terapi Islam Makassar: Berkah Utami, 2009.

Albar, Muhammad, Amar al-Mar'ah Fii al-Mizan, diterjemahkan oleh Amir Hamzah Fachruddin, Wanita Karier dalam Timbangan Islam; Kodrat Kewanitaan, Emansipasi dan Pelecehan Seksual Jakarta: Pustaka Azzam, 2008.

al-Bukhari, Muhammad bin Ismail Abu Abdillah, Shahih Bukhari, Juz II Beirut: Dar Ibn Katsir, 1987.

al-Buthi, M. Said Ramadhan, Perempuan antara Kezaliman Sistem Barat dan Keadilan Islam Solo: Intermedia, 2012.

al-Ghazali, Mohammad, Al-Islam wa Al-Thaqat al-Mu'attalat Kairo: Dar AlKutub Al-Haditsah,

al-Ghazali, Mohammad, Ihya 'Ulumuddin, tentang Keajaiban Hati Jakarta: Yayasan Kesejahteraan Keluarga, 1965.

Aly, Hery Nur dan Munzir S., Watak Pendidikan Islam Jakarta: Friska Agung Insani, 2013.

Arikunto, Suharsimi, Prosedur Penelitian; Suatu Pendekatan Praktis Jakarta: Rineka Cipta, 2011.

Asmuni, H.M. Yusran, Dirasah Islamiyah, Fokus Kajian Fiqh, Jakarta : Pt Raja Grafindo Persada, 2001

Azra, Azyumardi, Pendidikan Islam Tradisi dan Modernisasi Menuju Millenium Baru, Jakarta: Kalimah, 2002.

bin Hambal, Ahmad, Musnad al-Imam Ahmad bin Hambal Beirut, Al-Maktab alIslami, Daar al-Sadeer, 2008.

Budiningsih, Asri, Pembelajaran Moral Berpijak pada Karakteristik Siswa dan Budayanya Jakarta: Rineka Cipta, 2009.

Daradjat, Zakiah,"Peran Ganda dan Kepemimpinan Perempuan" dalam Lily Zakiah Munir [ED], Memposisikan Kodrat: Perempuan dan Perubahan dalam Perspektif Islam Bandung: Mizan, 2009.

Daryanto, S.S. Kamus Bahasa Indonesia Lengkap Surabaya: Apollo, t.th.

Departemen Agama RI. Al-Qur'an dan Terjemahnya, Jakarta: Gema Risalah Press Bandung, 2009.

Departemen Pendidikan dan Kebudayaan, Kamus Besar Bahasa Indanesia Jakarta, Balai Pustaka, 2007.

Farozin, Muh. \& Kartika Nur Fathiyah, Pemahaman Tingkah Laku Yogyakarta: Rineka Cipta, 2003.

Fatimah, Nasib Umar, Menggugat Sejarah Perempuan"Mewujudkan Idealisme Jender Sesuai Tuntutan Islam, Jakarta: Cendekia Sentra Muslim, 1993. 
Gibran, Kahlil, dalam M. Rusli Karim, Mendidik Manusia Merdeka Yogyakarta: Pelita Baru, 1997.

Hadi, Sutrisno, Metodologi Research Jakarta: UGM Press, 2010.

Harb, Muhammad Thal'at, Solusi Islam terhadap Dilema Wanita Karier Yogyakarta: Wihdah Press, 2014.

Hartati, Netty, dkk., Islam dan Psikologi Jakarta: RajaGrafindo Persada, 2005.

Ibrahim bin Ali al-Wazir, 'Ala Masyarif Al-Qarn Kairo, Dar Al-Syuruq, 1998.

Khomaini, Imam dalam Majalah Payam Khonewodeh No: 52, $1384 \mathrm{H}$.

Langgulung, Hasan, Beberapa Tinjauan dalam Pendidikan Islam Jakarta: Pustaka Antara, 1980.

Mahmud, Jamaluddin Muhammad, Huquq Al-Mar'at fi Al-Mujtama' al-Islamiy Kairo, Al-Haiat al-Mishriyat al-Amat, 2006.

Mahzar, Armahedi "Wanita dalam Islam" kata pengantar, dalam buku Fatima Mernissi, Woman And Islam: An Historical and Theological Enqiury diterjemahkan oleh Yasiar Radianti dengan judul Wanita dalam Islam Bandung: Pustaka, 2011.

Mernissi, Fatima, Woman And Islam: An Historical and Theological Enqiury Bandung: Pustaka, 2009.

Muhajir, Noeng, Metode Penelitian Kualitatif Yogyakarta: Rake Sarasin, 2009.

Munir, Lily Zakiah (ED), Memposisikan Kodrat: Perempuan dan Perubahan dalam Perspektif Islam Bandung: Mizan, 2009.

Narbuko, Cholid dan Abu Achmadi, Metodologi Penelitian Jakarta: Bumi Aksara, 2010.

Pasaribu dan Simanjuntak, Proses Belajar Mengajar Bandung: Tarsito, 1982.

Poerwanto, M. Ngalim, Ilmu Pendidikan Teoritis dan Praktis Bandung: Remaja Rosdakarya, 2008.

Purwanto, Ngalim, Psikologi Pendidikan Bandung: Remaja Karya, 2010.

Shihab, Umar, Menggugat Sejarah Perempuan"Mewujudkan Idealisme Jender Sesuai Tuntutan Islam, Jakarta: Cendekia Sentra Muslim, 2009.

Sjarkawi, Pembentukan Kepribadian Anak; Peran Moral, Intelektual, Emosional, dan Sosial sebagai Wujud Integritas Membangun Jati Diri Jakarta:. Bumi Aksara, 2011.

Subagyo, Joko, Metode Penelitian dalam Teori dan Praktek Jakarta: Rineka Cipta, 2011.

Sukardi, Metodologi Penelitian Pendidikan Kompetensi dan Praktiknya Jakarta: Bumi Aksara, 2005.

Sukmadinata, Nana Syaodih, Landasan Psikologi Proses Pendidikan Bandung: Remaja RosdaKarya, 2005.

Suryabrata, Sumadi, Psikologi Kepribadian Jakarta: RajaGrafindo Persada, 2006.

Syalaby, Ahmad, Kehidupan Sosial dalam Kehidupan Islam T.t: Amzah, 2011. 
Umar, Nasarudin, Argumen Kesetaraan Gender; Perspektif Al-Quran Jakarta; Paramadina, 1999.

Warsito, Hermawan, Pengantar Metodologi Penelitian, Buku Panduan Mahasiswa Jakarta: Gramedia Utama, 2007. 